\title{
Effect on Lipids in Liver and Serum, and Some Urinary Components of Dietary Supplement of Excess Lysine Given to Previously Starved or Non-starved Rats
}

\author{
Yoritaka Aoyama, Takanori NisHII and Akira YosHidA \\ Department of Agricultural Chemistry, School of Agriculture, \\ Nagoya University, Furo-cho, Chikusa, \\ Nagoya 464-01, Japan \\ Received March 27, 1989
}

\begin{abstract}
In order to obtain further information on the changes in liver lipids, either a basal or a lysineexcess diet was refed to previously starved rats or fed to previously non-starved rats. Liver lipid accumulation was observed in previously starved rats refed the lysine-excess diet for 7 days, but not in rats without previous starvation. The liver lipid did not accumulate with another 8 days' feeding ( 15 days' refeeding). The addition of methionine alone or in combination with threonine to the lysineexcess diet had no effect on the liver lipid level. The decrease in serum triacylglycerol in rats refed the lysine-excess diet was preceded by lipid accumulation in the liver. Urinary potassium during the initial two days increased with refeeding and feeding. Marked excretion of orotate was observed for $\mathbf{2}$ days from the initiation of refeeding of the lysine-excess diet and it then decreased. Thus, such a marked increase in the urinary excretion of orotate might be associated with the stimulation of orotate biosynthesis and with lipid accumulation in the liver.
\end{abstract}

Lipid accumulation in the liver of rats induced by the addition of orotic acid to the diet was first reported by Standerfer and Handler. ${ }^{\text {) }}$ An arginine deficient diet has also been shown to cause lipid accumulation in rat liver. ${ }^{2)}$ Lipid accumulation in the liver of rats fed either an orotic acid diet or an arginine-deficient diet was prevented by the addition of adenine, allopurinol or corn oil. ${ }^{3 \sim 6)}$ Orotic aciduria is associated with arginine-deficiency. Serum triacylglycerol and cholesterol were reduced in rats fed either an orotic acid diet or an arginine-deficient diet. ${ }^{4,6,8}$

The addition of an excess amount of lysine to a diet containing $15 \%$ casein and $0.3 \%$ methionine resulted in lipid accumulation in the liver. $^{9 \sim 11)}$ This is similr to the lipid accumulation in the liver of rats fed either an orotic acid diet or an arginine-deficient diet. In fact, Ulman et al. ${ }^{12)}$ reported orotic aciduria caused by feeding excess lysine to growing rats. However, serum triacylglycerol and cholesterol were not depressed in rats fed a diet containing $15 \%$ casein, $0.3 \%$ methionine and
$5 \%$ lysine hydrochloride.

The response of serum lipids to feeding a diet containing excess lysine was not similar to that observed in rats fed either an orotic acid diet or an arginine-deficient diet. Whereas, Aoyama et al. ${ }^{13)}$ observed that lipids in the liver were accumulated in previously starved rats refed a lysine-excess diet and the decrease in serum triacylglycerol was followed by lipid accumulation in the liver.

The present studies were designed to determine whether methionine alone or in combination with threonine added is essential for lipid accumulation in the liver, and whether or not the alterations in the serum lipids and urinary excretion are associated with the lipid accumulation in the liver.

\section{Methods}

Male Wistar strain rats (Shizuoka Laboratory Animal Center, Hamamatsu, Shizuoka, Japan) were housed individually in screen bottom-cages in a temperature controlled room $\left(23^{\circ} \mathrm{C}\right)$. The composition of the basal diet is 
Table II. Effect of the Dietary Addition of Methionine Alone or Both Methionine and Threonine to a Basal or a Lysine-excess Diet Refed for 3 or 7 Days after 3 Day's Starvation on Food Intake, Body Weight Gain, Liver Weight, Liver Lipids and Serum Lipids

\begin{tabular}{|c|c|c|c|c|c|c|c|c|c|}
\hline Expt. & Diet & $\begin{array}{l}\text { Period of } \\
\text { refeeding } \\
\text { (days) }\end{array}$ & $\begin{array}{l}\text { Initial }^{1} \\
\text { body wt } \\
\text { (g) }\end{array}$ & $\begin{array}{l}\text { Food intake } \\
\text { (g/3 or } 7 \text { days) }\end{array}$ & $\begin{array}{l}\text { Body wt gain } \\
\text { (g/3 or } 7 \text { days) }\end{array}$ & $\begin{array}{c}\text { Liver wt } \\
(\mathrm{g} / 100 \mathrm{~g} \text { body wt })\end{array}$ & $\begin{array}{l}\text { Liver lipids } \\
\text { (mg/g liver) }\end{array}$ & $\begin{array}{c}\text { Serum } \\
\text { triacylglycerol } \\
(\mathrm{mg} / 100 \mathrm{ml})\end{array}$ & $\begin{array}{c}\text { Serum } \\
\text { cholesterol } \\
(\mathrm{mg} / 100 \mathrm{ml})\end{array}$ \\
\hline \multirow{6}{*}{1} & Basal & 3 & $131.4 \pm 1.3^{2}$ & $44.1 \pm 1.1^{b}$ & $25.0 \pm 1.0^{\mathrm{ab}}$ & $4.90 \pm 0.15^{\mathrm{c}}$ & $131.0 \pm 9.0^{\mathrm{a}}$ & $102.8 \pm 9.2^{a}$ & $120.9 \pm 3.1^{\mathrm{a}}$ \\
\hline & Basal $+0.3 \%$ Met & 3 & $131.6 \pm 1.5$ & $42.1 \pm 0.8^{\mathrm{ab}}$ & $24.0 \pm 1.0^{\mathrm{ab}}$ & $4.94 \pm 0.20^{\mathrm{c}}$ & $109.3 \pm 10.6^{a}$ & $110.3 \pm 5.1^{\mathrm{a}}$ & $111.6 \pm 4.9^{\mathrm{a}}$ \\
\hline & Basal $+0.3 \% \mathrm{Met}+0.2 \% \mathrm{Thr}$ & 3 & $131.6 \pm 1.0$ & $43.0 \pm 1.6^{\mathrm{ab}}$ & $26.8 \pm 1.7^{\mathrm{a}}$ & $5.28 \pm 0.16^{\mathrm{bc}}$ & $119.1 \pm 6.9^{\mathrm{a}}$ & $107.6 \pm 3.3^{a}$ & $119.0 \pm 4.6^{\mathrm{a}}$ \\
\hline & Lys-excess & 3 & $131.6 \pm 0.8$ & $41.2 \pm 0.6^{\mathrm{ab}}$ & $22.2 \pm 1.5^{\mathrm{b}}$ & $5.54 \pm 0.24^{\mathrm{abc}}$ & $56.5 \pm 3.5^{\mathrm{b}}$ & $63.4 \pm 8.1^{\mathrm{b}}$ & $96.5 \pm 5.6^{\mathrm{b}}$ \\
\hline & Lys-excess $+0.3 \%$ Met & 3 & $131.6 \pm 1.2$ & $41.2 \pm 1.0^{\mathrm{ab}}$ & $22.4 \pm 0.9^{b}$ & $5.94 \pm 0.23^{\mathrm{a}}$ & $69.6 \pm 2.7^{b}$ & $60.2 \pm 6.2^{b}$ & $82.7 \pm 3.2^{\mathrm{c}}$ \\
\hline & Lys-excess $+0.3 \%$ Met $+0.2 \% \mathrm{Thr}$ & 3 & $131.6 \pm 1.0$ & $39.9 \pm 0.5^{b}$ & $21.6 \pm 0.7^{b}$ & $5.86 \pm 0.22^{\mathrm{ab}}$ & $64.1 \pm 5.8^{\mathrm{b}}$ & $61.4 \pm 9.0^{\mathrm{b}}$ & $85.6 \pm 0.8^{\mathrm{bc}}$ \\
\hline \multirow{6}{*}{2} & Basal & 7 & $134.0 \pm 2.2$ & $106 \pm 6^{\mathrm{ab}}$ & $48.2 \pm 3.2^{\mathrm{a}}$ & $3.69 \pm 0.14^{\mathrm{b}}$ & $50.9 \pm 1.6^{\mathrm{b}}$ & $77.4 \pm 8.9^{a}$ & $67.4 \pm 10.5^{b}$ \\
\hline & Basal $+0.3 \%$ Met & 7 & $134.4 \pm 1.3$ & $99 \pm 4^{b}$ & $49.0 \pm 2.5^{\mathrm{a}}$ & $3.98 \pm 0.25^{\mathrm{b}}$ & $52.5 \pm 0.9^{b}$ & $61.9 \pm 3.3^{\mathrm{a}}$ & $72.5 \pm 3.8^{\mathrm{b}}$ \\
\hline & Basal $+0.3 \%$ Met $+0.2 \% \mathrm{Thr}$ & 7 & $134.6 \pm 1.2$ & $103 \pm 1^{\mathrm{ab}}$ & $52.4 \pm 1.5^{\mathrm{a}}$ & $3.93 \pm 0.10^{\mathrm{b}}$ & $53.0 \pm 2.2^{\mathrm{b}}$ & $72.8 \pm 8.7^{\mathrm{a}}$ & $122.2 \pm 4.0^{\mathrm{a}}$ \\
\hline & Lys-excess & 7 & $133.8 \pm 1.9$ & $114 \pm 2^{\mathrm{a}}$ & $38.2 \pm 1.2^{\mathrm{b}}$ & $5.10 \pm 0.17^{\mathrm{a}}$ & $131.4 \pm 23.7^{\mathrm{a}}$ & $86.5 \pm 6.8^{\mathrm{a}}$ & $90.9 \pm 3.3^{b}$ \\
\hline & Lys-excess $+0.3 \% \mathrm{Met}$ & 7 & $134.4 \pm 1.1$ & $108 \pm 2^{a b}$ & $34.0 \pm 1.1^{\mathrm{bc}}$ & $5.61 \pm 0.31^{\mathrm{a}}$ & $181.1 \pm 35.4^{\mathrm{a}}$ & $58.6 \pm 8.4^{\mathrm{a}}$ & $90.0 \pm 9.3^{b}$ \\
\hline & Lys-excess $+0.3 \%$ Met $+0.2 \% \mathrm{Thr}$ & 7 & $134.2 \pm 1.0$ & $111 \pm 2^{\mathrm{ab}}$ & $31.2 \pm 2.1^{\mathrm{c}}$ & $5.23 \pm 0.08^{\mathrm{a}}$ & $164.9 \pm 25.2^{\mathrm{a}}$ & $72.8 \pm 8.7^{\mathrm{a}}$ & $96.2 \pm 8.6^{\mathrm{ab}}$ \\
\hline
\end{tabular}

1 Before 3 day's starvation.

2 Means \pm SEM for five rats. Means within a column not followed by the same letter in each experiment are significantly different $(p<0.05)$. 
Table III. Effect of Refeeding Either a Basal Diet or a Lysine-excess Diet for 0, 3, 7, 11 or 15 Days to Previously Starved Rats on Food Intake, Body Weight Gain, Liver Weight, Liver Lipids and Serum Lipids (Experiment 3)

\begin{tabular}{|c|c|c|c|c|c|c|c|c|}
\hline Diet & $\begin{array}{l}\text { Refeeding } \\
\text { period } \\
\text { (days) }\end{array}$ & $\begin{array}{l}\text { Initial }^{1} \\
\text { body wt } \\
\text { (g) }\end{array}$ & $\begin{array}{c}\text { Food intake } \\
(\mathrm{g} / 3,7,11,15 \text { days })\end{array}$ & $\begin{array}{c}\text { Body wt gian } \\
(\mathrm{g} / 3,7,11,15 \text { days })\end{array}$ & $\begin{array}{c}\text { Liver wt } \\
(\mathrm{g} / 100 \mathrm{~g} \text { body } \mathrm{wt})\end{array}$ & $\begin{array}{l}\text { Liver lipids } \\
\text { (mg/g liver) }\end{array}$ & $\begin{array}{c}\text { Serum } \\
\text { triacylglycerol } \\
(\mathrm{mg} / 100 \mathrm{ml})\end{array}$ & $\begin{array}{l}\text { Serum } \\
\text { cholesterol } \\
(\mathrm{mg} / 100 \mathrm{ml})\end{array}$ \\
\hline (Starved) & 0 & $128.4 \pm 1.5^{2}$ & - & - & $3.19 \pm 0.05^{f}$ & $69.4 \pm 2.4^{\text {de }}$ & $44.7 \pm 0.7^{\mathrm{e}}$ & $52.0 \pm 1.9^{d}$ \\
\hline $\begin{array}{l}\text { Basal } \\
\text { Lys-excess }\end{array}$ & $\begin{array}{l}3 \\
3\end{array}$ & $\begin{array}{l}129.8 \pm 2.2 \\
128.8 \pm 2.4\end{array}$ & $\begin{array}{l}43.6 \pm 1.4^{\mathrm{e}} \\
39.2 \pm 0.6^{\mathrm{e}}\end{array}$ & $\begin{array}{l}26.2 \pm 1.4^{\mathrm{f}} \\
21.4 \pm 0.5^{\mathrm{g}}\end{array}$ & $\begin{array}{l}5.53 \pm 0.11^{\mathrm{b}} \\
6.12 \pm 0.20^{\mathrm{a}}\end{array}$ & $\begin{array}{r}133.0 \pm 3.5^{\mathrm{b}} \\
72.0 \pm 7.9^{\text {de }}\end{array}$ & $\begin{array}{r}100.2 \pm 4.6^{\mathrm{b}} \\
66.6 \pm 6.9^{\mathrm{c}}\end{array}$ & $\begin{array}{l}128.8 \pm 4.5^{\mathrm{b}} \\
103.9 \pm 3.7^{\mathrm{c}}\end{array}$ \\
\hline $\begin{array}{l}\text { Basal } \\
\text { Lys-excess }\end{array}$ & $\begin{array}{l}7 \\
7\end{array}$ & $\begin{array}{l}128.6 \pm 0.9 \\
128.4 \pm 1.1\end{array}$ & $\begin{array}{l}119 \pm 3^{\mathrm{d}} \\
114 \pm 2^{\mathrm{d}}\end{array}$ & $\begin{array}{l}54.4 \pm 1.4^{\mathrm{d}} \\
40.2 \pm 0.9^{\mathrm{e}}\end{array}$ & $\begin{array}{l}4.81 \pm 0.21^{\mathrm{c}} \\
6.26 \pm 0.16^{\mathrm{a}}\end{array}$ & $\begin{array}{r}82.7 \pm 10.5^{\mathrm{d}} \\
176.7 \pm 12.3^{\mathrm{a}}\end{array}$ & $\begin{array}{l}101.5 \pm 9.5^{b} \\
118.8 \pm 8.7^{b}\end{array}$ & $\begin{array}{l}136.0 \pm 5.1^{\mathrm{ab}} \\
158.2 \pm 4.4^{\mathrm{a}}\end{array}$ \\
\hline $\begin{array}{l}\text { Basal } \\
\text { Lys-excess }\end{array}$ & $\begin{array}{l}11 \\
11\end{array}$ & $\begin{array}{l}128.8 \pm 1.7 \\
128.8 \pm 1.5\end{array}$ & $\begin{array}{l}204 \pm 3^{c} \\
193 \pm 8^{c}\end{array}$ & $\begin{array}{l}82.6 \pm 1.9^{b} \\
56.8 \pm 1.8^{d}\end{array}$ & $\begin{array}{l}4.37 \pm 0.03^{\mathrm{d}} \\
5.32 \pm 0.23^{\mathrm{b}}\end{array}$ & $\begin{array}{r}57.5 \pm 1.1^{\mathrm{e}} \\
111.0 \pm 12.2^{\mathrm{c}}\end{array}$ & $\begin{array}{l}125.1 \pm 10.8^{b} \\
118.3 \pm 9.3^{b}\end{array}$ & $\begin{array}{l}127.6 \pm 4.7^{b \mathrm{~b}} \\
146.7 \pm 8.5^{\mathrm{ab}}\end{array}$ \\
\hline $\begin{array}{l}\text { Basal } \\
\text { Lys-excess }\end{array}$ & $\begin{array}{l}15 \\
15\end{array}$ & $\begin{array}{l}128.8 \pm 0.9 \\
128.8 \pm 1.0\end{array}$ & $\begin{array}{l}285 \pm 3^{a} \\
271 \pm 6^{b}\end{array}$ & $\begin{array}{r}102.8 \pm 1.7^{\mathrm{a}} \\
77.6 \pm 2.6^{\mathrm{c}}\end{array}$ & $\begin{array}{l}3.80 \pm 0.06^{\mathrm{e}} \\
4.81 \pm 0.14^{\mathrm{c}}\end{array}$ & $\begin{array}{l}53.3 \pm 1.0^{\mathrm{e}} \\
64.4 \pm 4.5^{\mathrm{de}}\end{array}$ & $\begin{array}{l}178.4 \pm 10.8^{\mathrm{a}} \\
192.2 \pm 10.5^{\mathrm{a}}\end{array}$ & $\begin{array}{l}135.5 \pm 19.3^{\mathrm{ab}} \\
125.7 \pm 3.2^{\mathrm{bc}}\end{array}$ \\
\hline
\end{tabular}

1 Before 3 day's starvation.

2 Means \pm SEM for five rats. Means within a column not followed by the same letter are significantly different $(p<0.05)$. 
thionine alone or with both methionine and threonine, on refeeding for 3 days. Conversely, lipid accumulation was observed in the liver of rats refed the lysine-excess diet for 7 days. The addition of methionine alone or both methionine and threonine to the lysine-excess diet had no effect on liver lipid accumulation. Triacylglycerol and cholesterol in serum of rats refed the basal diet with or without methionine alone or with both methionine and threonine were significantly higher than those of rats refed the lysine-excess diet with or without methionira alone or with both methionine and threonine for 3 days. On refeeding for 7 days, no significant differences were observed in serum triacylglycerol among the six groups. The addition of both methionine and threonine to the basal diet caused an increasing tendency or a significant increase in serum cholesterol, on refeeding for 7 days.

Food intake, body weight gain, liver weight, liver lipids, serum triacylglycerol and serum cholesterol of rats refed either the basal diet or the lysine-excess diet for $0,3,7,11$ and 15 days after starvation for 3 days are shown in Table III. Food consumption of rats refed the lysineexcess diet for 3,7 or 11 days was similar to the corresponding value with the basal diet, respectively. The body weight gain of rats refed the basal diet was significantly higher than that in the case of the lysine-excess diet during the experimental periods. Refeeding caused an increase in liver weight and then a decrease in it. Liver lipids increased when rats were refed the basal diet for 3 days, and thereafter decreased. Whereas, refeeding the lysine-excess diet for 3 days had no effect on liver lipids but refeeding for 7 days resulted in a marked increase in liver lipids. The liver lipid level gradually decreased after refeeding the lysine-excess diet for 7 days. Serum triacylglycerol increased after refeeding the experimental diets. Serum triacylglycerol of rats refed the lysine-excess diet for 3 days was lower than that of rats refed the basal diet for 3 days. No differences between the two groups were observed in serum triacylglycerol after refeeding for 7, 11 and 15 days. Serum cholesterol also increased after refeeding the experimental diets. The values plateaued after refeeding the basal diet for 3 days and the lysine-excess diet for 7 days. Throughout the experimental periods, the serum cholesterol level was similar in the two groups.

Urinary excretion of rats refed the basal diet and the lysine-excess diet is shown in Table IV. Refeeding of the lysine-excess diet stimulated the excretion of urinary potassium on days $0 \sim 2$. Excess lysine resulted in a two-fold output of urinary potassium for the initial two days after refeeding. Urinary sodium in rats

Table IV. Potassium, Sodium and Orotate in Urine Excreted by Previously Starved Rats Refed Either a Basal Diet or a Lysine-excess Diet (Experiment 3).

\begin{tabular}{|c|c|c|c|c|c|}
\hline \multirow{2}{*}{$\begin{array}{c}\text { Urinary } \\
\text { components }\end{array}$} & \multirow[b]{2}{*}{ Diet } & \multicolumn{4}{|c|}{ Periods urine was collected after refeeding } \\
\hline & & \multicolumn{3}{|c|}{ ( $\mu \mathrm{eq} / 100 \mathrm{~g}$ body wt/2 days) } & $13 \sim 15$ \\
\hline Potassium & $\begin{array}{l}\text { Basal } \\
\text { Lys-excess } \\
p\end{array}$ & $\begin{array}{c}657 \pm 46^{1} \\
1379 \pm 43 \\
<0.001\end{array}$ & $\begin{array}{c}1370 \pm 94 \\
1550 \pm 41 \\
\mathrm{NS}^{2}\end{array}$ & $\begin{array}{c}1376 \pm 28 \\
1632 \pm 113 \\
\text { NS }\end{array}$ & $\begin{array}{c}1409 \pm 30 \\
1455 \pm 38 \\
\text { NS }\end{array}$ \\
\hline Sodium & $\begin{array}{l}\text { Basal } \\
\text { Lys-excess } \\
p\end{array}$ & $\begin{array}{c}3774 \pm 200 \\
3948 \pm 230 \\
\text { NS }\end{array}$ & $\begin{array}{c}4270 \pm 283 \\
4617 \pm 326 \\
\text { NS }\end{array}$ & $\begin{array}{c}3983 \pm 87 \\
4435 \pm 296 \\
\text { NS }\end{array}$ & $\begin{array}{c}3891 \pm 187 \\
4135 \pm 135 \\
\text { NS }\end{array}$ \\
\hline Orotate & $\begin{array}{l}\text { Basal } \\
\text { Lys-excess } \\
p\end{array}$ & $\begin{array}{c}4.43 \pm 0.30 \\
38.2 \pm 2.3 \\
<0.001\end{array}$ & $\begin{array}{r}1.87 \pm 0.3 \\
10.7 \pm 2.0 \\
<0.001\end{array}$ & $\begin{array}{c}2.08 \pm 0.15 \\
5.91 \pm 1.14 \\
\quad<0.02\end{array}$ & $\begin{array}{c}1.92 \pm 0.19 \\
7.92 \pm 1.41 \\
<0.001\end{array}$ \\
\hline
\end{tabular}

1 Means \pm SEM for five rats.

2 Not significant. 
Table V. Effect of Feeding Either a Basal Diet or a Lysine-excess Diet for 0,7 and 15 Days without Previous Starvation on Food Intake, Body Weight Gain, Liver Weight, LIVER LIPIDS AND SERUM LIPIDS (Experiment 4)

\begin{tabular}{lcccccccc}
\hline Diet & $\begin{array}{c}\text { Feeding } \\
\text { period } \\
\text { (days) }\end{array}$ & $\begin{array}{c}\text { Initial } \\
\text { body wt } \\
(\mathrm{g})\end{array}$ & $\begin{array}{c}\text { Food } \\
\text { intake } \\
(\mathrm{g} / 7 \text { or } \\
15 \text { days })\end{array}$ & $\begin{array}{c}\text { Body wt } \\
\text { gain } \\
(\mathrm{g} / 7 \text { or } \\
15 \text { days })\end{array}$ & $\begin{array}{c}\text { Liver } \\
\mathrm{wt} \\
(\mathrm{g} / 100 \mathrm{~g} \\
\text { body wt) }\end{array}$ & $\begin{array}{c}\text { Liver } \\
\text { lipids } \\
(\mathrm{mg} / \mathrm{g} \text { liver })\end{array}$ & $\begin{array}{c}\text { Serum } \\
\text { triacylglycerol } \\
(\mathrm{mg} / 100 \mathrm{ml})\end{array}$ & $\begin{array}{c}\text { Serum } \\
\text { cholesterol } \\
(\mathrm{mg} / 100 \mathrm{ml})\end{array}$ \\
\hline- & 0 & $116.4 \pm 0.8^{1}$ & - & - & $5.16 \pm 0.05^{\mathrm{b}}$ & $57.3 \pm 2.0^{\mathrm{a}}$ & $69.8 \pm 2.0^{\mathrm{c}}$ & $63.6 \pm 3.4^{\mathrm{b}}$ \\
Basal & 7 & $115.2 \pm 3.6$ & $118 \pm 3^{\mathrm{c}}$ & $39.4 \pm 1.7^{\mathrm{c}}$ & $4.57 \pm 0.09^{\mathrm{c}}$ & $49.4 \pm 0.6^{\mathrm{bc}}$ & $132.3 \pm 6.5^{\mathrm{ab}}$ & $99.9 \pm 2.2^{\mathrm{a}}$ \\
Lys-excess & 7 & $115.2 \pm 3.3$ & $112 \pm 4^{\mathrm{c}}$ & $22.6 \pm 1.4^{\mathrm{d}}$ & $5.49 \pm 0.04^{\mathrm{a}}$ & $44.6 \pm 2.5^{\mathrm{c}}$ & $114.0 \pm 9.7^{\mathrm{b}}$ & $96.7 \pm 5.6^{\mathrm{a}}$ \\
Basal & 15 & $115.2 \pm 2.3$ & $275 \pm 7^{\mathrm{a}}$ & $87.2 \pm 5.4^{\mathrm{a}}$ & $4.04 \pm 0.04^{\mathrm{d}}$ & $54.8 \pm 1.6^{\mathrm{ab}}$ & $169.1 \pm 24.6^{\mathrm{a}}$ & $89.9 \pm 6.8^{\mathrm{a}}$ \\
Lys-excess & 15 & $115.2 \pm 2.8$ & $256 \pm 3^{\mathrm{b}}$ & $55.0 \pm 2.4^{\mathrm{b}}$ & $4.06 \pm 0.08^{\mathrm{c}}$ & $52.2 \pm 0.9^{\mathrm{ab}}$ & $169.8 \pm 24.9^{\mathrm{a}}$ & $110.3 \pm 12.8^{\mathrm{a}}$ \\
\hline
\end{tabular}

1 Means \pm SEM for five rats. Means within a column not followed by the same letter are significantly different $(p<0.05)$.

Table VI. Potassium, Sodium and Orotate in Urine Excreted When Rats were Fed Either a Basal Diet or a Lysine-excess Diet without Previous Starvation (Experiment 4)

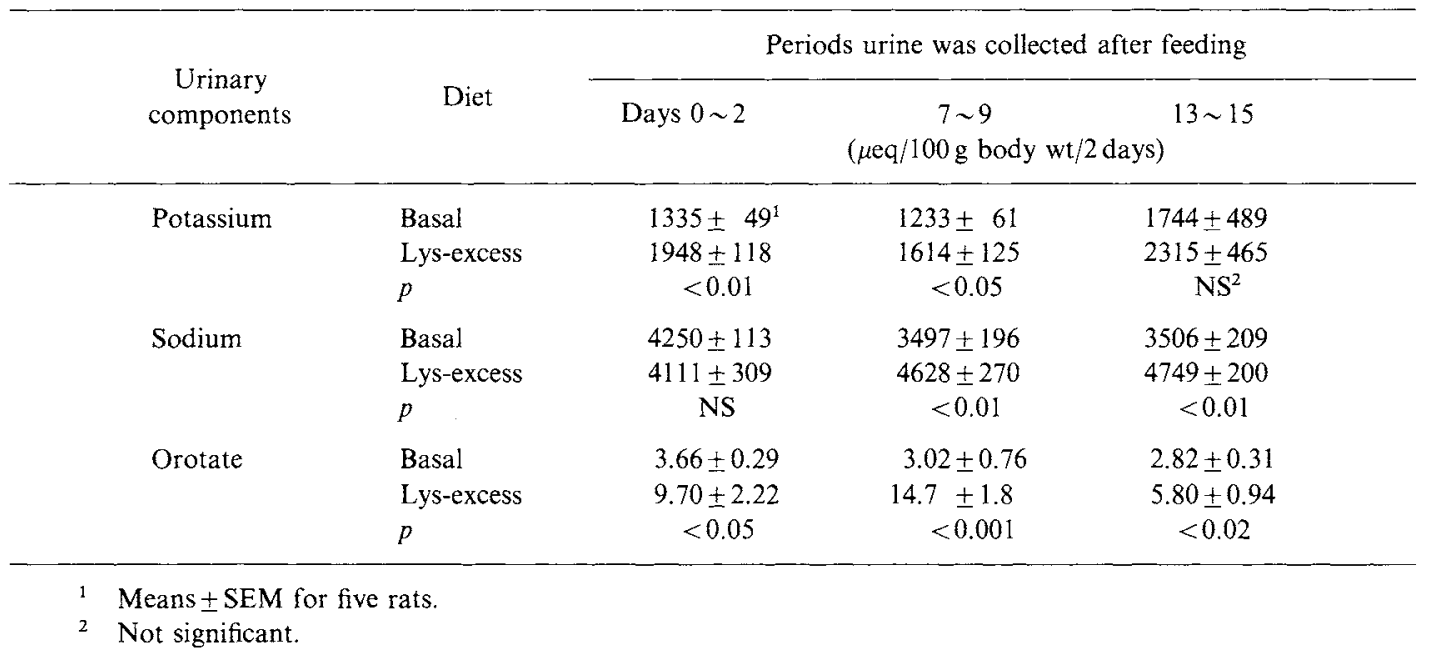

refed the lysine-excess diet was similar to that in the case of the basal diet in each period urine was collected. Urinary orotate excreted by rats refed the lysine-excess diet in each period was significantly higher than that in rats refed the basal diet. The addition of excess lysine resulted in marked excretion of orotate during the initial two days after refeeding.

The effects of feeding either the basal diet or the lysine-excess diet for 0,7 and 15 days to previously non-starved rats on food intake, body weight gain, liver weight, liver lipids, serum triacylglycerol and serum cholesterol are shown in Table V. There were no differences in food intake between the two groups for 7 days, but the food consumption of rats fed the basal diet for 15 days was significantly higher than that in the case of the lysine-excess diet. The body weight gain of rats fed the basal diet for 7 or 15 days was significantly higher than that in the case of the lysine-excess diet, respectively. Feeding of the lysine-excess diet resulted in liver enlargement. Whereas, liver lipids, and triacylglycerol and cholesterol in serum were not affected by the addition of excess dietary lysine. Serum triacylglycerol in- 
cresed with increasing time of feeding.

When rats were fed either the basal diet or the lysine-excess diet, urinary potassium, sodium and orotate were as shown in Table VI. Potassium excretion was more increased in rats fed the lysine-excess diet than in rats fed the basal diet, except on days $13 \sim 15$. Sodim excretion by rats fed the lysine-excess diet was at first similar to that in the case of the basal diet (days $0 \sim 2$ ) and then increased (days $7 \sim 9$ and $13 \sim 15$ ). Excess dietary lysine caused an increase in urinary orotate.

\section{Discussion}

Feeding experiments were conducted using diets comprising a $6 \%$ casein diet supplemented with various amino acid mixtures to determine the sequence in which the amino acids of casein become limiting for the growth of young rats. ${ }^{23)}$ It was concluded that sulfurcontaining amino acids are the most limiting; threonine next; then tryptophan, isoleucine, histidine, valine and phenylalanine, which are about equally limiting; then lysine, which is slightly less limiting than the preceding 6; and finally arginine, the lest limiting. Therefore, the effects of the dietary addition of methionine alone or of both methionine and threonine to either a basal diet or a lysine-excess diet on food intake, body weight gain, liver lipids and serum lipids were examined. As can be seen in Table II, no significant changes in the parameters tested were observed. Therefore, in the following experiments (experiments 3 and 4), methionine or/and threonine were not added.

Refeeding the lysine-excess diet for 7 days to previously starved rats resulted in lipid accumulation in the liver (experiment 2 in Table II and experiment 3 in Table III). On refeeding for 10 or 15 days, the hepatic lipid level returned to the level before refeeding (experiment 3 in Table III). These results support that feeding the lysine-excess diet for 7 or 15 days to previously non-starved rats failed to increase liver lipids, as compared with the corresponding values in rats fed the basal diet, respectively (experiment 4 in Table V).
Urinary excretion of potassium was markedly increased during the initial period urine was collected after refeeding the lysine-excess diet (Table IV). Feeding the lysine-excess diet led to an increasing tendency of urinary excretion of potassium (Table VI). Walker et $a l{ }^{24)}$ reported that the infusion of lysine into dogs resulted in extracellular acidosis. High concentrations of lysine caused the production of alkaline urine and increased bicarbonate excretion, despite the extracellular acidosis. They postulated that lysine infusion produced renal cellular alkalosis, thereby reducing proton secretion and increasing potassium secretion. While, there were no significant changes in the urinary excretion of sodium in rats refed a basal diet and a lysine-excess diet.

Ulman et al. ${ }^{12)}$ have demonstrated the increased output of urinary orotate when nonstarved rats were fed a lysine-excess diet, which produced lipid accumulation in the liver. In the present study, hepatic lipid accumulation was temporarily observed in rats refed (Table III), but not in rats fed the lysine-excess diet (Table V). Urinary excretion of orotate was stimulated in rats either fed or refed the lysine-excess diet (Tables IV and VI). The marked increase on days $0 \sim 2$ in the urinary excretion of orotate might be associated with the stimulation of pyrimidine biosynthesis in the liver. ${ }^{25}$ ) Furthermore, it is surmised that the concentration of orotate in the liver might be high when the excretion of urinary orotate increases. Thus, this is similar to the metabolic changes observed when rats were fed an orotic acid diet. Therefore, the metabolic interactions can be summarized as follows: marked excretion of orotate, as described above, followed by a decrease in serum triacylglycerol after refeeding for 3 days (experiment 3 in Tables III and IV). The decrease in serum triacylglycerol was preceded by liver lipid accumulation in the liver after refeeding of previously starved rats for 7 days. Urinary orotate was excreted more in the initial two days (days $0 \sim 2$ ) after refeeding the lysine-excess diet to previously starved rats (Table IV) than in the initial two days (days $0 \sim 2$ ) after feeding the 
lysine-excess diet to previously non-starved rats (Table VI). Thus, lipid accumulation in the liver produced by refeeding (Table III), but not by feeding a lysine-excess diet (Table V), might be due to the difference in the amount of urinary orotate.

\section{References}

1) S. B. Standerfer and P. Handler, Proc. Soc. Exp. Biol. Med., 90, 270 (1955).

2) J. A. Milner and E. G. Perkin, Lipids, 13, 563 (1978).

3) R. E. Handschmacher, W. A. Creasey, J. J. Jaffe, C. A. Pasternack and L. Hankin, Proc. Natl. Acad. Sci. U.S.A., 36, 178 (1960).

4) J. A. Milner, J. Nutr, 109, 663 (1979).

5) Y. Aoyama and K. Ashida, Nutr. Rep. Inter., 20, 483 (1979).

6) Y. Aoyama, A. Yoshida and K. Ashida, J. Nutr., 111, 895 (1981).

7) J. A. Milner and W. J. Visek, Metabolism, 24, 643 (1975).

8) H. G. Windmueller and A. E. Spaeth, J. Biol. Chem., 241, 2891 (1966).

9) P. Hevia and W. J. Visek, Lipids, 15, 95 (1980).

10) P. Hevia, F. W. Kari, E. A. Ulman and W. J. Visek, J. Nutr., 110, 1224 (1980)
11) P. Hevia, E. Ulman, F. W. Kari and W. J. Visek, J. Nutr., 110, 1231 (1980).

12) E. A. Ulman, F. W. Kari, P. Hevia and W. J. Visek, J. Nutr., 111, 1772 (1979).

13) Y. Aoyama, K. Sakaida, A. Yoshida and K. Ashida, Brit. J. Nutr., 50, 627 (1983).

14) P. B. Rama Rao, H. W. Norton and B. C. Johnson, J. Nutr., 73, 38 (1961).

15) Y. Aoyama, H. Yasui and K. Ashida, J. Nutr., 101, 739 (1971).

16) J. Folch, M. Lees and G. H. Sloane Stanley, J. Biol. Chem., 226, 497 (1957).

17) A. W. Wahiefeld, Methods of Enzymatic Analysis, 4, 1831 (1974).

18) S. Pearson, S. Stern and T. H. McGavack, Anal. Chem., 25, 813 (1953).

19) C. Tsutsumi, H. Koizumi and S. Yoshikawa, Rept. Natl. Food Res. Inst., 34, 132 (1979).

20) H. Möllering, Methods of Enzymatic Analysis, 4, 1959 (1974).

21) D. B. Duncan, Biometrics, 11, 1 (1955).

22) G. W. Snedecor and W. G. Cochran, "Statistical Methods," The Iowa State University Press, Ames, 1967.

23) A. E. Harper, J. Nutr., 67, 109 (1959).

24) G. W. Walker, H. Dickerman and L. J. Host, Am. J. Physiol., 206, 409 (1964).

25) A. S. Hassan and J. A. Milner, Arch. Biochem. Biophys., 194, 24 (1979). 